\author{
MARTÍN OLMEDO MUÑOZ \\ FACULTAD DE FILOSOFÍA Y LETRAS, UNAM
}

\title{
La visión del mundo agustino en Meztitlán Ideales y virtudes en tres pinturas murales
}

\begin{abstract}
D l análisis de la pintura mural novohispana tiene una larga tradición historiográfica en México. Desde los primeros estudios de pintura Lacerca de la Nueva España se ha mostrado su importancia y su papel primordial en el arte. El presente trabajo analiza tres casos del amplio panorama de la pintura mural del siglo Xvi. Este grupo de obras se encuentra en el Convento de Meztitlán, actual estado de Hidalgo. La primera se ubica en un luneto, arriba de la puerta de acceso al refectorio del convento (figs. Ia y Ib). Hasta ahora el único historiador que la ha mencionado es Constantino Reyes Valerio; ${ }^{\mathrm{I}}$ por tanto, presento una interpretación iconográfica detallada del tema, motivos y posibles influencias indígenas del estilo de la imagen. En la segunda parte del estudio indagaré acerca de dos pinturas murales localizadas en la escalera del conjunto arquitectónico, donde se encuentran los llamados Triunfos de la Castidad y de la Paciencia (figs. 2-5).
\end{abstract}

I. "En el muro norte del refectorio del convento agustino de Metztitlán, Hidalgo, se conserva un mural con el tema de la Tebaida. En el centro tiene una figura bastante maltratada de Cristo crucificado y bajo su brazo derecho aparece un cacto del que se desprende un chorro de líquido a la manera prehispánica, es decir, con las gotas de agua en el extremo; al pie de la cruz se encuentra una serpiente de cascabel (cóatl) y un conejo (tochtli, en náhuatl). En el mismo edificio la figura de la luna se repite por todas partes; quizás se le ha utilizado como topónimo del lugar, puesto que Metztli quiere decir luna y tlán lugar, en lengua náhuatl", Constantino Reyes Valerio, Arte indocristiano, México, Instituto Nacional de Antropología e Historia, 2000, p. I78. 
a)

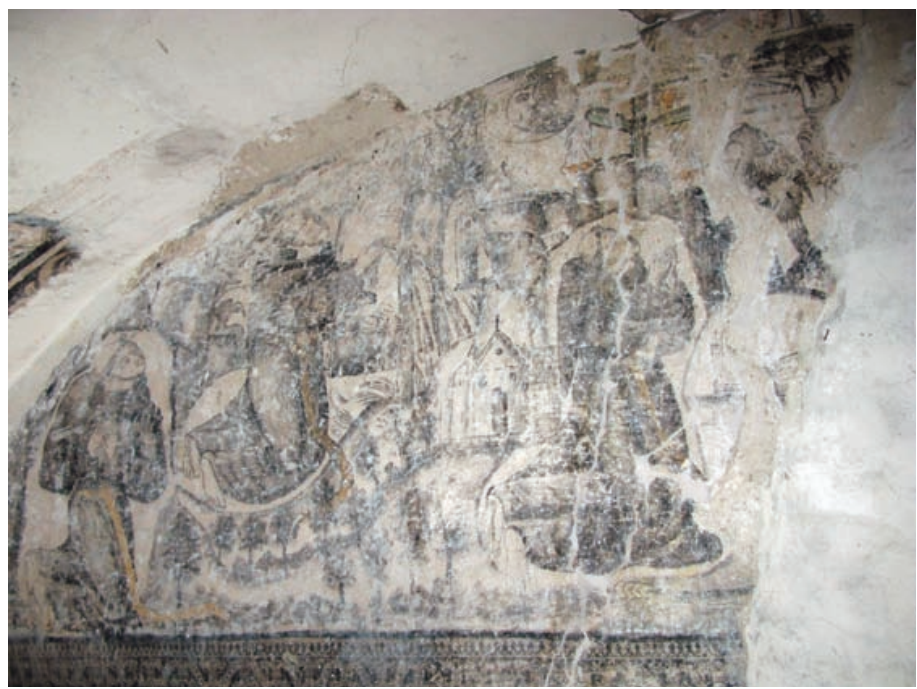

b)

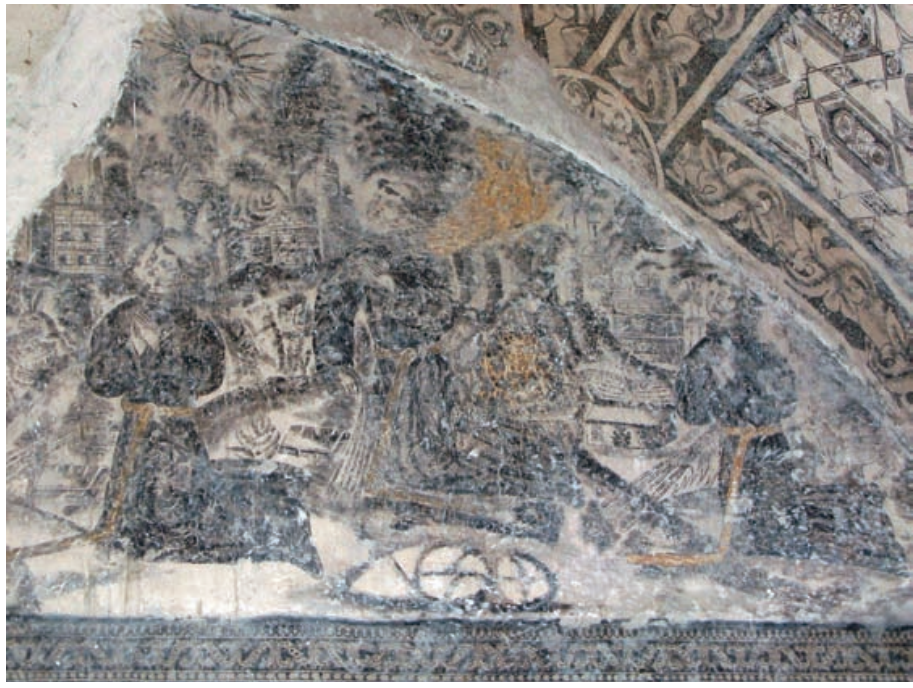

I. Pintura mural del refectorio del Convento de Meztitlán; a) lado derecho y b) lado izquierdo. Foto: Martín Olmedo Muñoz. Reproducción autorizada por el Instituto Nacional de Antropología e Historia. Conaculta-INAH-Méx. 


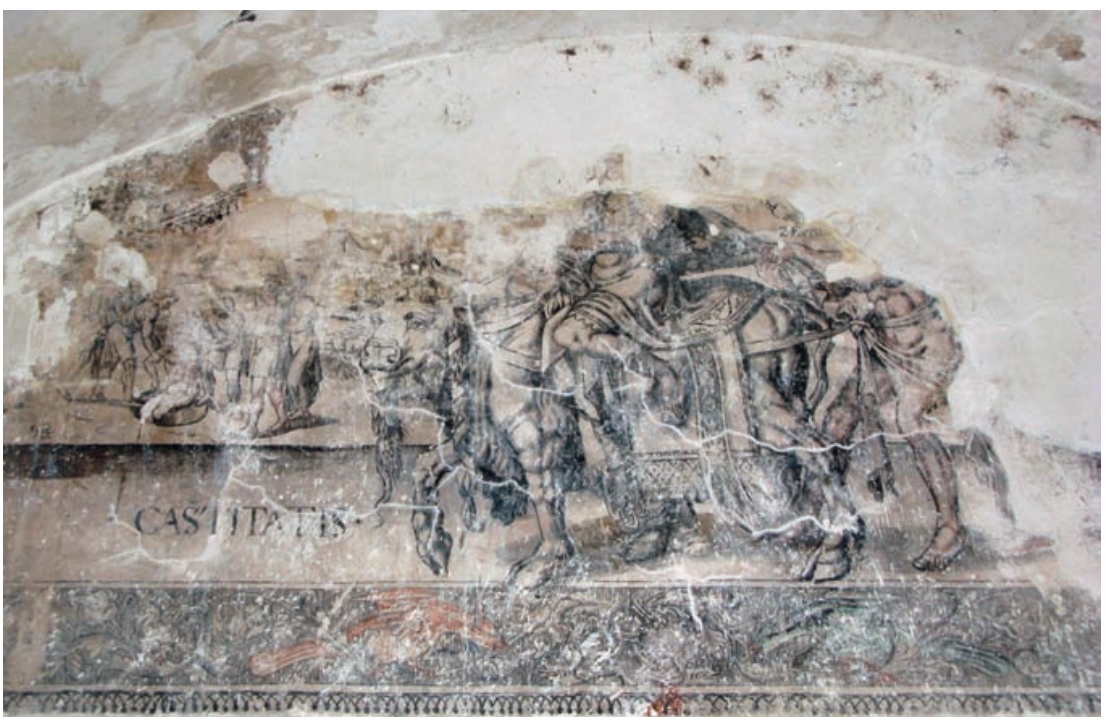

2. Pintura mural del Triunfo de la Castidad en la escalera del Convento de Meztitlán. Foto: Martín Olmedo Muńoz. Reproducción autorizada por el Instituto Nacional de Antropología e Historia. Conaculta-INAH-Méx.

El investigador Erwin W. Palm fue el primero en relacionar las pinturas y una serie de grabados; publicó los resultados de su búsqueda en un breve artículo $^{2}$ donde apunta que los pintores del convento agustino copiaron las imágenes de un ciclo de Maarten van Heemskerck, concebido en I559 y grabado en I562. La fuente de inspiración fue una obra literaria de Hadrianus Junius, quien, "al reunir epigramas sobre los triunfos de Petrarca con otros sobre las virtudes cristianas, revela ser la fuente de toda la Contrarreforma que sirve de programa común para los murales de Meztitlán y de la Casa del Deán de Puebla". ${ }^{3}$ Estudiaré cada uno de los motivos iconográficos de estas dos pinturas, su relación con la emblemática, su papel dentro de la visión del mundo agustino y las virtudes promovidas por esta orden novohispana en la segunda mitad del siglo XvI.

2. Erwin W. Palm, "Los murales del Convento Agustino de Metztitlán", Comunicaciones, México, Fundación Alemana para la Investigación Científica/Proyecto Puebla-Tlaxcala, núm. I3, I976, pp. I-3.

3. Ibidem, p. 2. 


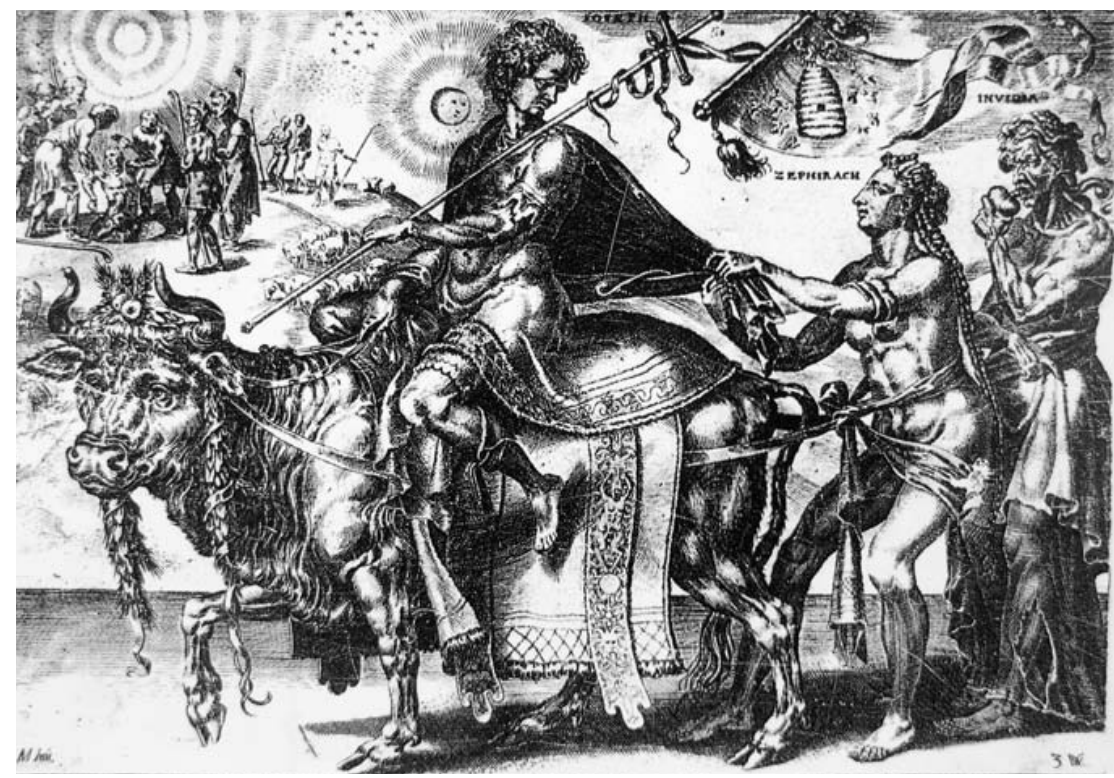

3. Maarten van Heemskerck, Triunfo de la Castidad, grabado, impreso y publicado por Dirck Volckertszoon Coornhert. Imagen tomada de González de Zárate (ed.), op. cit. (infra n. 24), p. 32.

\section{Los frailes eremitas agustinos adoran a Cristo en tierras novohispanas}

La historiografía ha demostrado que la pintura del luneto del refectorio del convento expresa uno de los temas más frecuentes del arte conventual del siglo xvi: la tebaida. Reyes Valerio y, especialmente, Antonio Rubial ${ }^{4}$ han resaltado la importancia de esta iconografía en los muros de los conventos agustinos. Más allá de estas interpretaciones, desglosaré cada uno de los motivos y personajes de la pintura para demostrar que ésta, en virtud de la iconografía y la cultura pictórica de sus creadores, ostenta más elementos que la mera

4. Antonio Rubial García, "Hortus eremitarum. Las pinturas de tebaidas en los claustros agustinos", Anales del Instituto de Investigaciones Estéticas, vol. XXX, núm. 92, primavera de 2008, pp. 85-105. 


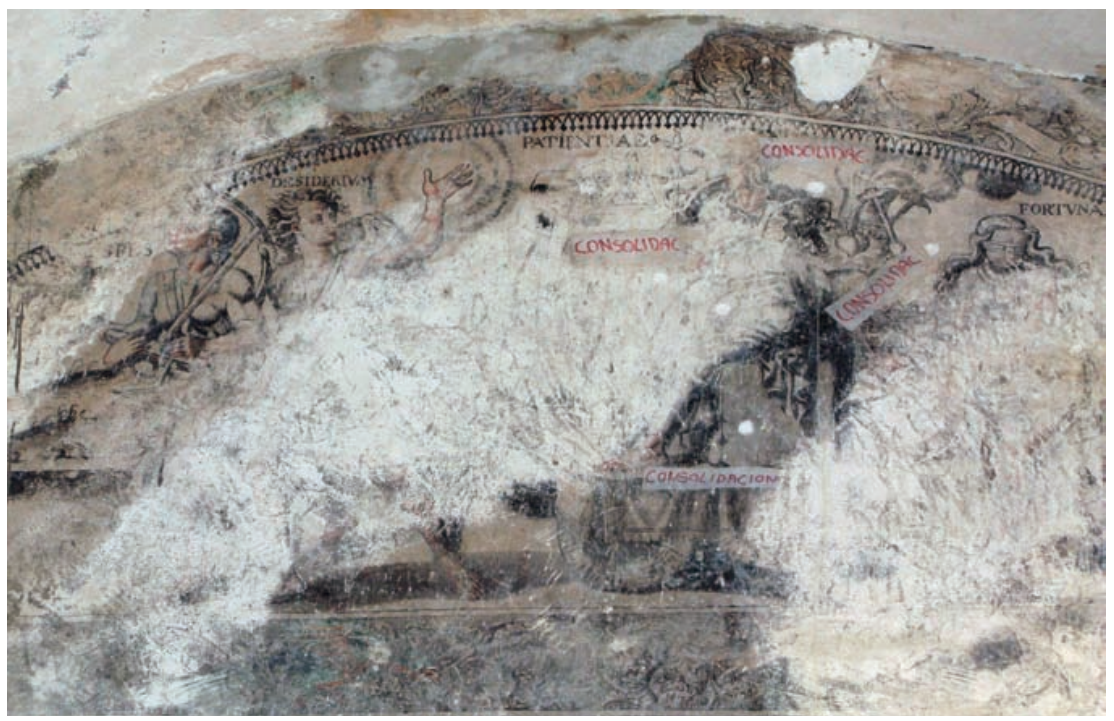

4. Pintura mural del Triunfo de la Paciencia en la escalera del Convento de Meztitlán. Foto: Martín Olmedo Muñoz. Reproducción autorizada por el Instituto Nacional de Antropología e Historia. Conaculta-InAH-Méx.

representación de los ermitaños en un ambiente natural, como generalmente se ha figurado la tebaida.

En el primer plano, se observa a seis frailes agustinos con cinturón de cuero, hábito negro y tonsura, postrados ante un Cristo crucificado. Todo parece indicar que los pintores no representaron santos agustinos, puesto que no poseen ningún atributo evidente y los únicos elementos reiterados son los numerosos libros a sus pies y los flagelos que sostienen en las manos. Por medio de estos elementos iconográficos se describen, por un lado, los deberes del eremita agustino: la lectura constante de los textos evangélicos y, por otro, el fraile con el flagelo como emulador de los apóstoles; los religiosos de la orden buscan seguir estos pasos: el sufrimiento y la propagación de la palabra de Jesús. En el siglo xvi se consideraba que este tipo de penitencia física tenía el propósito de recuperar el estado de gracia espiritual. Según tal planteamiento, los frailes no eran pecadores y, por tanto, con la "mortificación de la carne" pretendían generar más virtud, acercarse cada vez más a una estado de santidad. El Concilio de Trento fomentó así el uso del flagelo: 


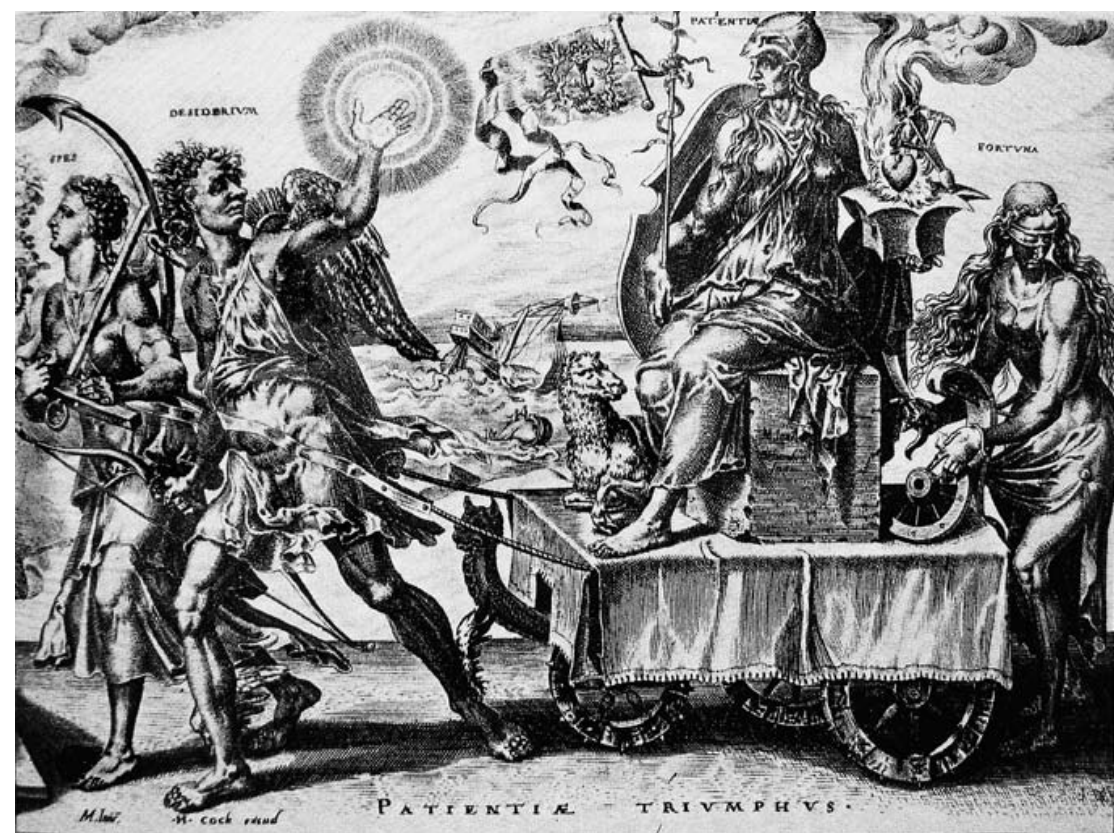

5. Maarten van Heemskerck, Triunfo de la Paciencia, grabado, impreso y publicado por Dirck Volckertszoon Coornhert. Imagen tomada de González de Zárate (ed.), op. cit. (infra n. 24), p. 32.

Justificados pues los hombres de este modo, hechos ya amigos y domésticos de Dios, y caminando de virtud en virtud, se renuevan, como dice el Apóstol (Efesios, I), de día en día, esto es, que mortificando su carne, y sirviéndose de ella como de instrumento para justificarse y santificarse, mediante la observancia de los mandamientos de Dios, y de la Iglesia, crecen en la misma santidad que por la gracia de Cristo han recibido, y cooperando la fe con la buenas obras, se justifican más. ${ }^{5}$

Los agustinos novohispanos expresaron en su pintura elementos coincidentes con los postulados tridentinos; así, colocaron en su refectorio - lugar donde generalmente se mostraban figuras sobresalientes de las órdenes religiosas-

5. El sacrosanto y ecuménico Concilio de Trento, Madrid, Imprenta Real, I785, sesión VI, cap. X, "Del aumento de la justificación después de haberla obtenido", p. 58 (las cursivas son mías). 


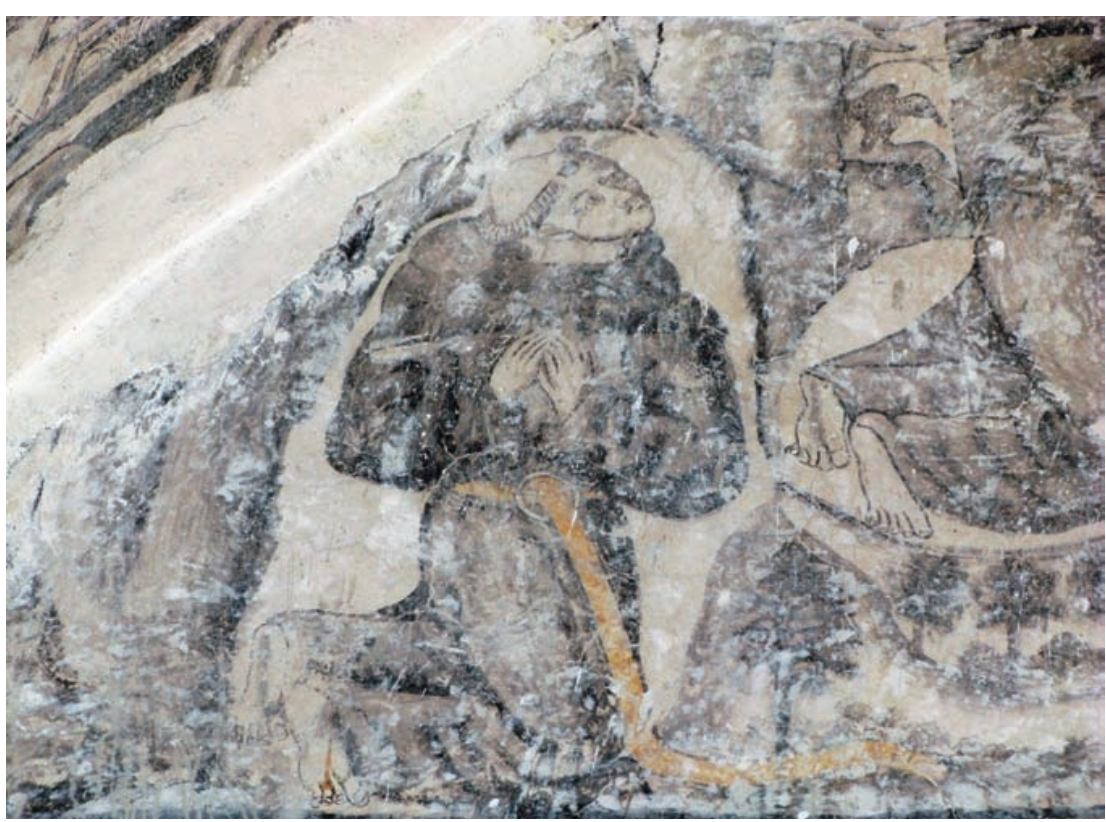

6. Detalle de los pies desnudos de los frailes, pintura mural del Convento de Meztitlán, lado izquierdo. Foto: Martín Olmedo Muñoz.

sus propios cuerpos, considerados generadores de gracia por medio del flagelo y la lectura de textos teológicos.

El segundo aspecto que debemos tomar en cuenta es la conformación del paisaje, lograda con trazos ondulantes que dan la sensación de un terreno accidentado con muchos árboles en los alrededores. Varias construcciones delimitan el entorno de los religiosos. Tres llaman la atención del observador: dos iglesias en la parte central izquierda y una construcción cuadrangular en la esquina derecha. La distribución del espacio y la representación de la figura humana y animal nos muestran la unión con otras imágenes de pintores indígenas del siglo Xvi novohispano. Por ejemplo, observamos que sobresalen los pies desnudos del segundo fraile, de izquierda a derecha, ya que la vestidura le cubre las piernas hasta el tobillo; tales pies se hallan colocados de frente y sus uñas se aprecian marcadas con pequeños círculos, lo que cambia la perspectiva del cuerpo (fig. 6). Esta manera de representar los pies y la posición del cuerpo coincide con importantes rasgos pictóricos de los códices indígenas 


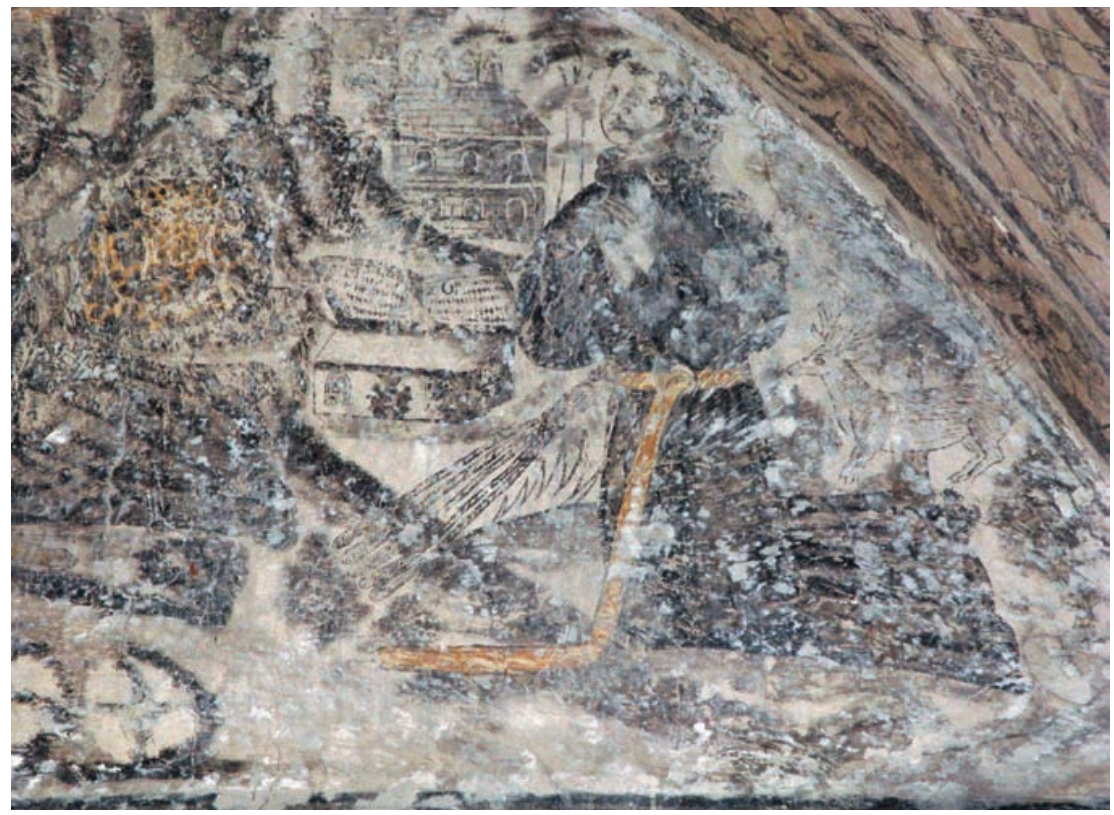

7. Detalle de un venado en la pintura mural del refectorio del Convento de Meztitlán. Foto: Martín Olmedo Muñoz.

prehispánicos y del siglo xvI. ${ }^{6}$ Arriba se observa un cacto con tres extremidades, de las cuales parten trazos que crean el efecto de una corriente de agua (fig. Ia). Inmediatamente abajo, los pintores colocaron una serie de cuatro círculos pintados de amarillo. De igual forma, la representación del venado en el extremo derecho de la pintura nos da indicios de la tradición indígena (fig. 7), pues observamos figuraciones de este animal en el Códice florentino, donde hallamos gran similitud en la forma, en los trazos del pelo del animal y en la pequeñez de las patas.

El lado derecho de la imagen tiene características compositivas similares a las del izquierdo. Entre los dos frailes y un conejo observamos un tipo de cactácea (fig. 8). Es importante resaltar estos elementos "naturales", que algunos investigadores llaman "de la tierra", en la iconografía de los conventos agusti-

6. Véase Pablo Escalante Gonzalbo, Los códices mesoamericanos antes y después de la Conquista. Historia de un lenguaje pictográfico, México, Fondo de Cultura Económica, en prensa. 


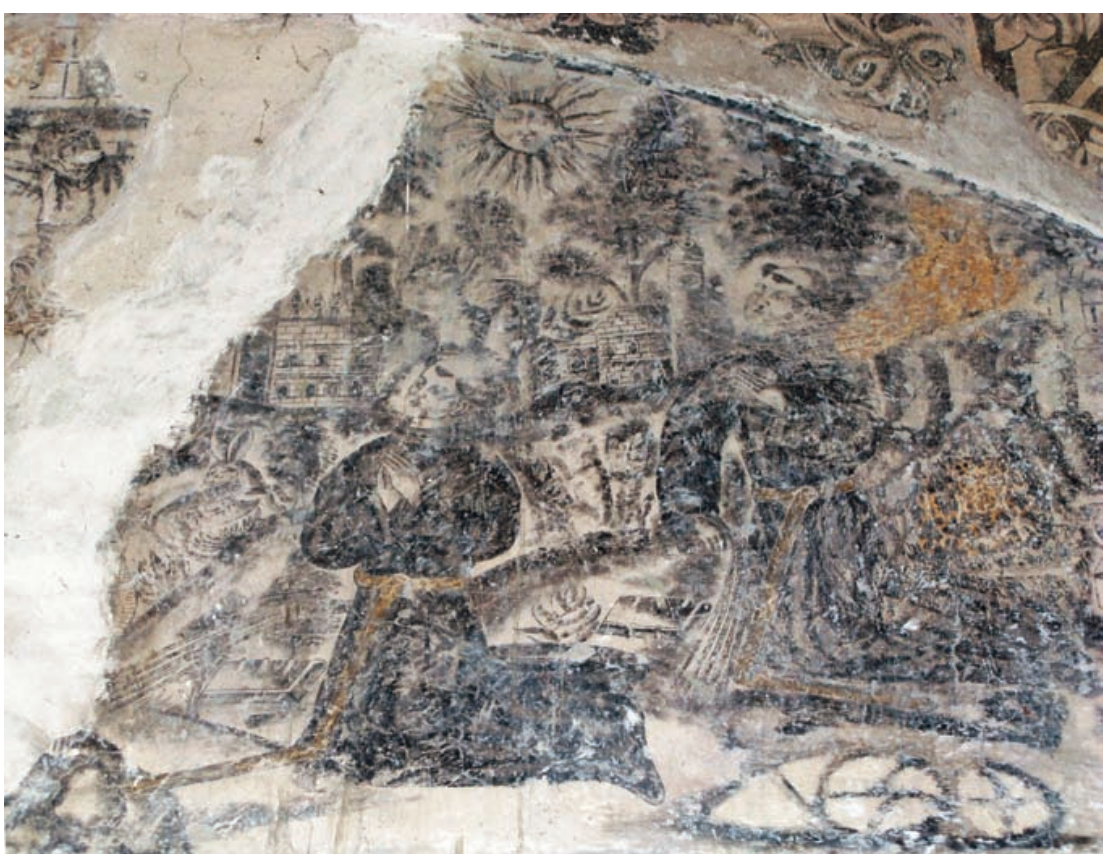

8. Detalle del lado derecho de la pintura mural del Convento de Meztitlán. Foto: Martín Olmedo Muńoz.

nos, sobre todo si tomamos en cuenta la disputa entre criollos y peninsulares a partir de la segunda mitad del siglo Xvi. ${ }^{7}$ Todavía se necesita profundizar en el sentido iconográfico de estos motivos, para determinar si forman parte de la reafirmación pictórica de una congregación novohispana (de criollos), de la justificación política del adueñamiento del espacio regional, del discurso iconográfico propio de una época de inquietudes "naturalistas" o de un sentido

7. Antonio Rubial García propone 1572 como una nueva etapa en las relaciones entre los dos grupos dentro de los agustinos. Por primera vez el grupo "de nacidos en la tierra" era más amplio que el de los peninsulares en el Convento de la Ciudad de México. "A partir de aquí el grupo criollo comenzó a ser mayoría en la orden y a tener en sus manos los puestos directivos de ella" (El convento agustino y la sociedad novohispana [1533-1630], México, Universidad Nacional Autónoma de México-Instituto de Investigaciones Históricas, 1989, p. 24). Véase más información en Antonio Rubial, "Votos pactados. Las prácticas políticas entre los mendicantes novohispanos", Estudios de Historia Novohispana, núm. 26, enero-junio de 2002, pp. 5I-83. 
teológico de locus amoenus con implicaciones en la liturgia — por ejemplo, en el caso del convento agustino de Malinalco. ${ }^{8}$ Antonio Rubial sugiere en un artículo que los animales de la obra comentada — presentes en la mayoría de las pinturas murales de tebaidas agustinas novohispanas del siglo XVI- son seres simbólicos de la psicomaquia cristiana; se trata, en su opinión, de fauna

emblemática de la vida eremítica: el león, símbolo paradigmático de la fortaleza espiritual de los ermitańos; el ciervo, cuya habilidad de cazar serpientes en sus cuevas lo asocia con aquellos que luchan con el Demonio y lo vencen; el ave que ataca a un conejo, emblema que habla de la castidad que triunfa sobre la lujuria. ${ }^{?}$

Respecto a la pintura del Convento de Meztitlán, podemos observar que los cambios estilísticos evidencian que dos pintores con características propias participaron en la pintura. Por ejemplo, los frailes del lado derecho tienen la misma postura que sus antecesores; sin embargo, se utilizó otra pincelada para definir sus cabelleras: en los primeros se marcó su volumen por medio de pequeñas líneas, mientras que, a partir del cuarto religioso, el cabello se rellenó con un trazo más grueso. Lo mismo sucedió con la vestimenta, donde el uso de la línea es menos definido y no se marcan las divisiones de las piernas, como en los agustinos del lado derecho; en estos casos se refuerzan los pliegues por medio de cambios de color, pues se combinan blancos y negros. En ese sentido, los frailes de la imagen tienen una postura menos marcada hacia el frente, la unión de sus manos se aprecia con mayor nitidez (sobre todo en las líneas que separan los dedos), y el cuello, que se encuentra cubierto por la tela, no resalta. Otro cambio fundamental son los pies, en este caso tapados por el hábito. Tales variaciones de estilo señalan la colaboración de dos manos en la pintura.

El entorno de los religiosos ofrece suficientes pistas para entender el tema de la pintura. Encuentro indicios para reconocer el paisaje en la pintura de la Relación geográfica de la villa de Meztitlán del alcalde mayor de dicha provincia, Gabriel de Chávez, de I579 (fig. 9a). Al final de la Relación..., un mapa muestra los principales puntos de la región, sus límites administrativos y construcciones

8. Véase Jeannette Favrot Peterson, The Paradise Garden Murals of Malinalco. Utopia and Empire in Sixteenth-Century Mexico, University of Texas Press, I993. Véase también Isabel Estrada de Gerlero, "El sentido simbólico-litúrgico en los murales del claustro del Convento Agustino de la Purificación y San Simón de Malinalco", en Homenaje a Marco Dorta. Anuario de Estudios Americanos, Sevilla, Escuela de Estudios Hispanoamericanos, I984, vol. XXXVIII, pp. 567-598. 9. Rubial, "Hortus eremitarum...", op. cit. 


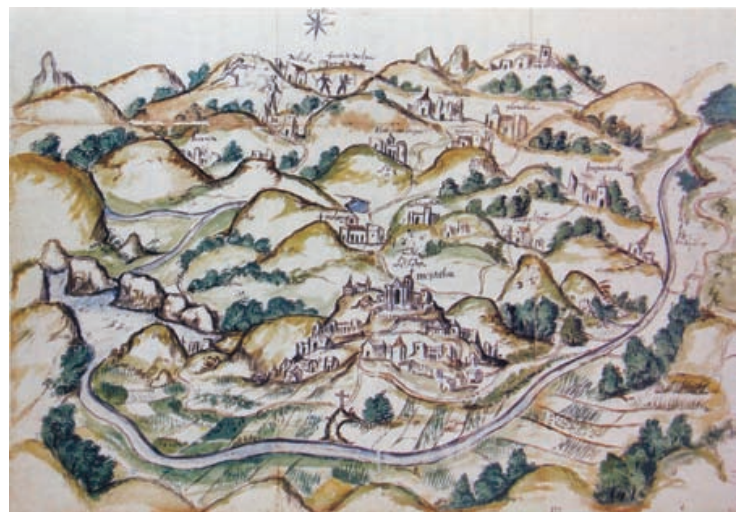

a)

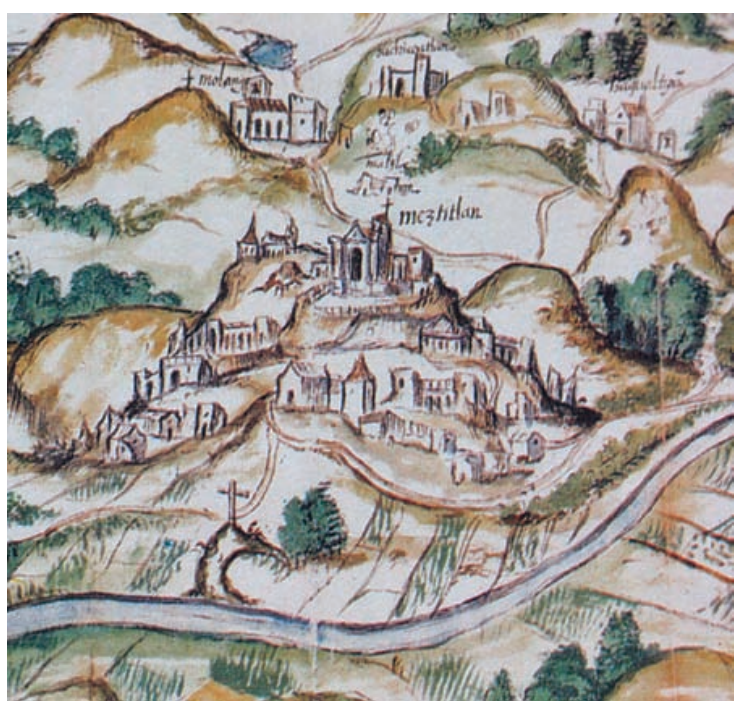

b)

9a) Mapa de la Relación geográfica de la villa de Meztitlán, tomado de René Acuńa (ed.), Relaciones geográficas del siglo XVI: México, México, Universidad Nacional Autónoma de México, I985, t. II, vol. 7, p. 58; b) detalle de la región de Meztitlán del mapa arriba señalado. 
principales. Si observamos sólo el área de Meztitlán en el mapa (fig. 9b), notaremos una similitud estilística entre el tratamiento formal de las iglesias de la imagen de la Relación... y los conventos representados en la pintura del refectorio (fig. Io). Las formas son muy similares: un rectángulo define la nave de la iglesia, el cual remata con un triángulo y una punta - en la pintura mural tiene una cruz grande, tan pequeña, en cambio, que, en el mapa de la Relación..., resulta casi indistinguible. Los pintores utilizaron el mismo recurso pictórico en las puertas y ventanas de las construcciones: se colocó medio óvalo alargado pintado de negro para figurar la puerta; a los lados se dispusieron dos rectángulos como las partes laterales de la iglesia. Con base en estos elementos, distinguimos en las dos imágenes influencias estilísticas que nos permiten atribuir una posible fecha a la pintura mural del refectorio: alrededor de 1579.

En el lado derecho de la pintura mural, los autores colocaron una construcción cuadricular con una puerta muy decorada. Considero que, a partir de la distribución espacial del mapa, en el muro del refectorio los frailes representaron el edificio de la "Tercena" de la villa de Meztitlán (fig. 7). Podemos determinar que lo es gracias a sus características arquitectónicas, que, de acuerdo con varios investigadores, hacen de ese inmueble uno de los primeros de la región, aunque todavía no se han definido sus usos. ${ }^{\text {Io }}$

Frente a esto, es posible definir la iconografía de la pintura: los frailes agustinos adoran a Cristo crucificado en la región de Meztitlán. En este aspecto, el mapa de la Relación... de Chávez puede brindarnos más recursos para el análisis. Varios cerros rodean el convento con cruces en las puntas en la representación "cartográfica" de la provincia, entre las cuales resalta la que está situada exactamente enfrente del convento, al lado de la vega, por su color blanco y su tamaño. ${ }^{\text {II }}$ Esa cruz sobre el cerro puede ser la representación del Jesús crucificado del

Io. Juan Benito Artigas señala que pudo haber sido el cabildo indígena. En opinión de Sara Cantú Treviño, se trataba de un depósito para recibir y guardar el tributo y los diezmos. Véanse Juan B. Artigas, Metztitlán, Hidalgo. Arquitectura del siglo XVI, México, Universidad Nacional Autónoma de México-Facultad de Arquitectura, 1996 y Sara Cantú Treviño, "La vega de Metztitlán en el estado de Hidalgo", Boletín de la Sociedad Mexicana de Geografia y Estadística, México, t. LXXV, núms. I-3. La construcción de la pintura mantiene la estructura rectangular del probable plano del conjunto realizado por el arquitecto Artigas. El dibujo de la perspectiva del edificio virreinal se encuentra en Artigas, op. cit., p. 69, fig. 59.

I I. Los investigadores Federico Fernández Christlieb y Gustavo Garza Merodio explican, basados en los testimonios de los residentes locales, que esta representación es la loma Quimixtepec o "cerrito de la Luna", aunque, por no ser objetivo de su investigación, no explican por qué en el mapa aparece el cerro con una cruz tan grande, exactamente enfrente del convento, y por qué 


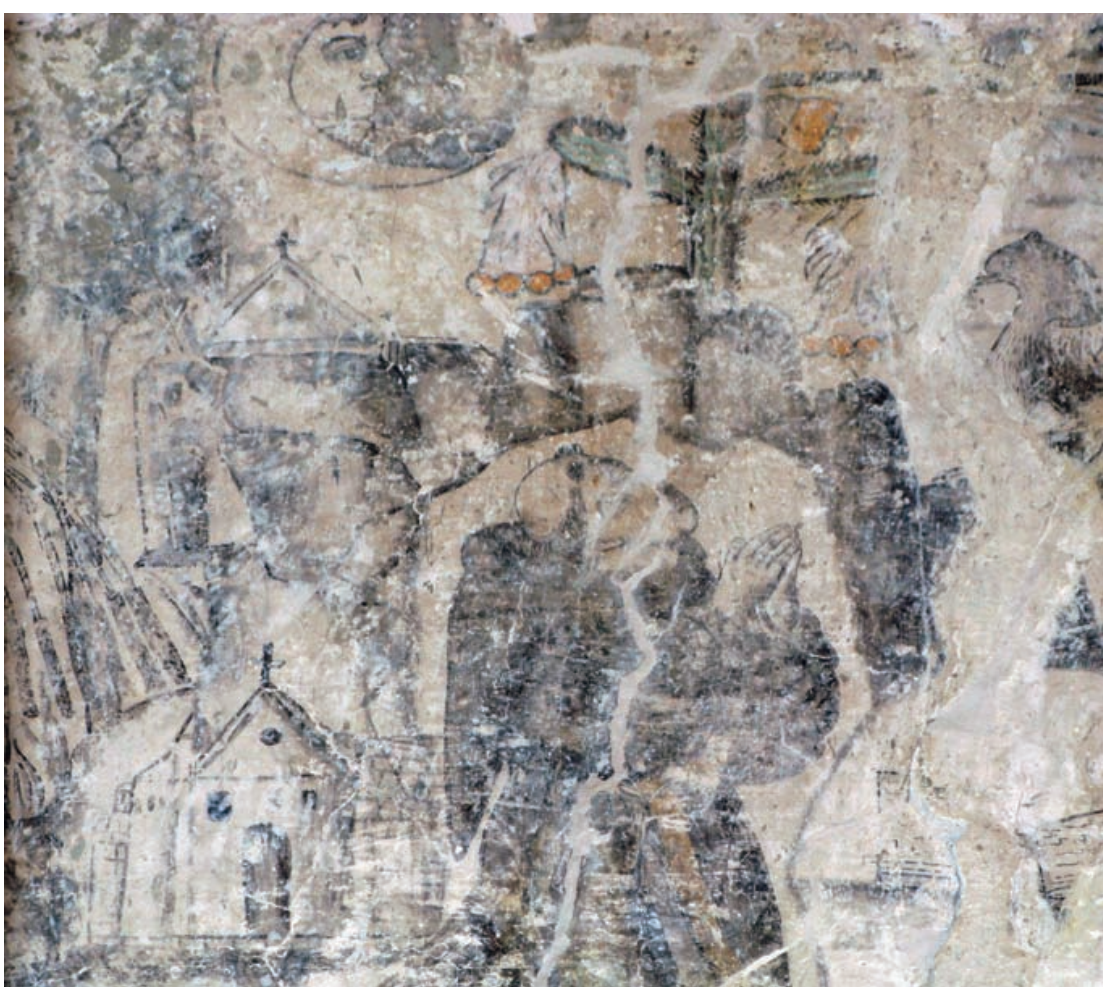

Io. Detalle del cacto cruciforme con los chalchihuites en la pintura del refectorio y las iglesias. Foto: Martín Olmedo Muńoz.

refectorio, donde los frailes, observando más allá de sus sentidos "comunes", logran percibir al "Cristo glorioso" en la cruz de las alturas. Sólo encuentro algunas diferencias entre la perspectiva del "mapa" ${ }^{2}$ y la pintura mural: la representación del alcalde busca destacar la vega y el convento principal — como "cabeza" del gobierno civil y los pueblos de visita sujetos de la cabecera. Por ser una "vista"

está pintada con tanto detalle. Todavía se necesita ahondar más sobre este punto iconográfico. Federico Fernández Christlieb y Gustavo Garza Merodio, "La pintura de la Relación geográfica de Metztitlán, I579”, Secuencia, núm. 66, septiembre-noviembre de 2006, pp. I63-I86.

I2. Fernández Christlieb y Garza Merodio indican que el término más adecuado para nombrar la pintura de la Relación... es "panorama" o "vista" de la villa, ya que no mantiene las características cartográficas básicas de perspectiva y distribución de los elementos, ibidem, p. I67. 
de carácter civil, resaltan las tierras para siembra, las montañas, las aguas, las construcciones e incluso las zonas "peligrosas" de los chichimecas, representadas por medio de hombres con arcos y flechas en el tope de la proyección. Por otro lado, en el falso fresco del refectorio, los frailes con los pintores simbolizaron una visión, es decir, una mirada de algo más allá de la perspectiva "real", pues desde el punto de vista devocional "la divinidad no se comunica realmente sino imaginariamente" ${ }^{13} \mathrm{Al}$ mismo tiempo, el observador creyente del siglo XVI concibe un episodio fundacional de los frailes agustinos.

De esta manera, se modificó la perspectiva del espectador, ya que el punto de observación parte del cerro: la loma es el punto de partida —el primer plano-, así como la devoción de los frailes. A partir de este principio iconográfico, podemos percibir las construcciones que rodean a ese monte y, en particular, las dos iglesias: una es posiblemente la primera construcción agustina en Meztitlán: el edificio conocido como "El Convento de Comunidad", ${ }^{14} \mathrm{y}$, arriba, la actual construcción del Convento de los Santos Reyes. La "comunidad", en el mapa de la Relación..., es representada por una estructura rectangular horizontal con dos rectángulos verticales a los lados y varias líneas centrales; si se observa desde un punto lejano, mantiene la distribución espacial de planos registrada tanto en el mapa como en la pintura mural. ${ }^{15}$ Los astros celestes son fundamentales para identificar el sentido espacial de la pintura. En los mapas del siglo XvI, las figuras de los astros se utilizan para precisar la ubicación de los puntos cardinales y como espacios de referencia para localizar territorialmente los objetos. ${ }^{16}$ En consecuencia, en la pintura del convento, el Sol marca la dirección del Oriente y la Luna el Poniente, adecuándose a la dirección del mapa de la Relación..., donde el Norte se especifica por medio de una rosa de los vientos o una estrella, según la cual el convento de la villa tiene su portada en dirección al Sur.

En ese sentido, se mantiene la división espacial y el paisaje de la pintura, donde la zona central es delimitada por el cerro con el Cristo crucificado; del lado izquierdo, la construcción de piedra de donde brota el nopal cruciforme

13. Victor I. Stoichita, El ojo mistico. Pintura y visión religiosa en el Siglo de Oro español, Anna María Coderch (trad.), Madrid, Alianza, 1996, p. 29.

I 4. Artigas, op. cit., pp. 53 y ss. Según este autor, dicho edificio se creó para resguardar a los frailes mientras se realizaba la construcción del convento actual.

15. Fernández Christlieb y Garza Merodio, op. cit., fig. 2.

I6. Véase Alessandra Russo, El realismo circular. Tierras, espacios y paisajes de la cartografía novohispana, siglos XVI y XVII, México, Universidad Nacional Autónoma de México-Instituto de Investigaciones Estéticas, 2005, pp. 23 y ss. 
- un acercamiento al Cristo en la composición, pues los dos elementos comparten el mismo plano-, las iglesias —el ámbito religioso- y, del lado derecho, las construcciones civiles. Así, se crea un ambiente de equilibrio entre las dos partes de la pintura del refectorio y se mantienen las relaciones espaciales representadas en el mapa de 1579 .

Después de analizar estos aspectos, encontramos una mezcla de componentes en la figuración del refectorio. Por un lado, se pintó la devoción de los frailes al Jesús crucificado y a éstos como imitadores y estudiosos de la vida de su guía espiritual. Por otro, los aspectos formales del paisaje nos remiten a cuestiones pictóricas cercanas a los mapas del siglo xvi. El nopal cruciforme evoca la unión entre los tres motivos iconográficos (fig. Io): el Cristo crucificado, los flagelos de los frailes y el nopal cruciforme. La imagen expresa el uso pictográfico de la cultura prehispánica y la tradición europea de esa centuria. El círculo amarillo con los trazos acuáticos, representación del chalchihuite, se emplea en algunos casos para mostrar la sangre - como se observa en diversas láminas del Códice Borgia y en otros documentos prehispánicos. Este elemento, junto con el nopal, remite al árbol sangrante prehispánico. ${ }^{17}$ Por lo tanto, el pictograma, Cristo en la cruz y los flagelos brindan suficientes bases para concluir que a) el sacrificio y la sangre de Cristo son importantes en el proceso de redención; b) los frailes, como contenedores de gracia santificadora, fomentan y ayudan al proceso de salvación por medio de su sangre, y c) el uso de pictogramas indígenas da lugar a un mensaje cristiano que constituye un discurso proveniente de dos tradiciones culturales. En definitiva, la experiencia de la visión y la "sangre redentora" requerían un espacio y, como en otras pinturas, el suceso se lleva a cabo sobre un ambiente natural novohispano. ${ }^{18}$ Las líneas que definen las pendientes, los árboles y las construcciones civiles y religiosas revelan que, para los frailes agustinos, el proceso de salvación marcado por la segunda etapa evangelizadora está llevándose a cabo en la zona de Meztitlán.

I7. Pablo Escalante Gonzalbo señala: "Desde la época olmeca el motivo de los círculos concéntricos se utiliza para representar el agua en contextos religiosos, y por lo menos setecientos ańos antes de la conquista ya aparece relacionado indistintamente con el agua y con la sangre sacrificial", en "Cristo, su sangre y los indios. Exploraciones iconográficas sobre el arte mexicano del siglo XvI”, en Helga von Kügelgen (ed.), Herencias indígenas, tradiciones europeas y la mirada europea, Francfort, Vervuert Verlagsgesellschaft, 2002, p. 73.

I8. El historiador del arte Victor I. Stoichita resalta la necesidad y la utilidad de figurar el "ambiente natural" en la representación de la visiones durante los siglos xvi y xvir. Véase Stoichita, op. cit., pp. 29 y ss. 


\section{ElTriunfo de la Castidad $y$ de la Paciencia: un par de virtudes del eremita agustino}

Como hemos visto, la vida de los frailes relacionada con el ascetismo, la mortificación y la flagelación implicaba el desarrollo de numerosas virtudes acordes con el papel de "modelo de los fieles" de esos religiosos. Dos de ellas se representaron en el cubo de la escalera del convento. Los pintores, como ya se ha señalado, copiaron una serie de I 7 estampas del grabador Dirck Volckertszoon Coornhert, ${ }^{19}$ impresas por Hieronymus Cook, en las que se representaron los triunfos de varias virtudes a partir del modelo de Petrarca. Los frailes novohispanos decidieron usar sólo dos grabados: el Triunfo de la Castidad (fig. 3) y el Triunfo de la Paciencia (fig. 5) —si originalmente hubo más Triunfos... ya no queda ningún rastro de ellos. ${ }^{20}$ Palm demostró que los grabados fueron ideados hacia 1559 por Maarten van Heemskerck — quien se basó en el libro de Hadrianus Junius, médico del príncipe de Orania- y después grabados por distintas casas de impresión hacia 1562.

\section{El Triunfo de la Castidad}

Al subir por la escalera del convento, la primera imagen que se observa es el Triunfo de la Castidad. La pintura está muy deteriorada y sólo se distinguen algunos rasgos del diseño original. En general, los pintores novohispanos respetaron con mucho esmero el grabado de Coornhert, aunque modificaron la distribución del espacio para adaptarse a la estructura arquitectónica. Así, los personajes que en el grabado estaban en la parte superior se pintaron ahora en los extremos, pero la composición central de dicho grabado se representó exactamente y se respetó la distribución de las figuras humanas medulares.

En el primer plano resalta José, personaje del Antiguo Testamento, sobre un toro ricamente ornamentado y con un tocado desde el que caen dos arreglos a ambos lados de la cabeza. En la tradición pictórica del siglo XVI, dichos ornamentos se colocaban en los toros del sacrificio, a los que se llamaba enguirnal-

19. Véase Henk Bonger, The Life and Work of Dirck Volckertszoon Coornhert, Gerrit Voogt (trad.), Ámsterdam/Nueva York, Rodopi, 2004, pp. I4-39.

20. Palm propone que los otros triunfos cristianos de la serie de Job y David ocuparon las paredes laterales de la escalera de Meztitlán. Palm, op. cit., p. I. 


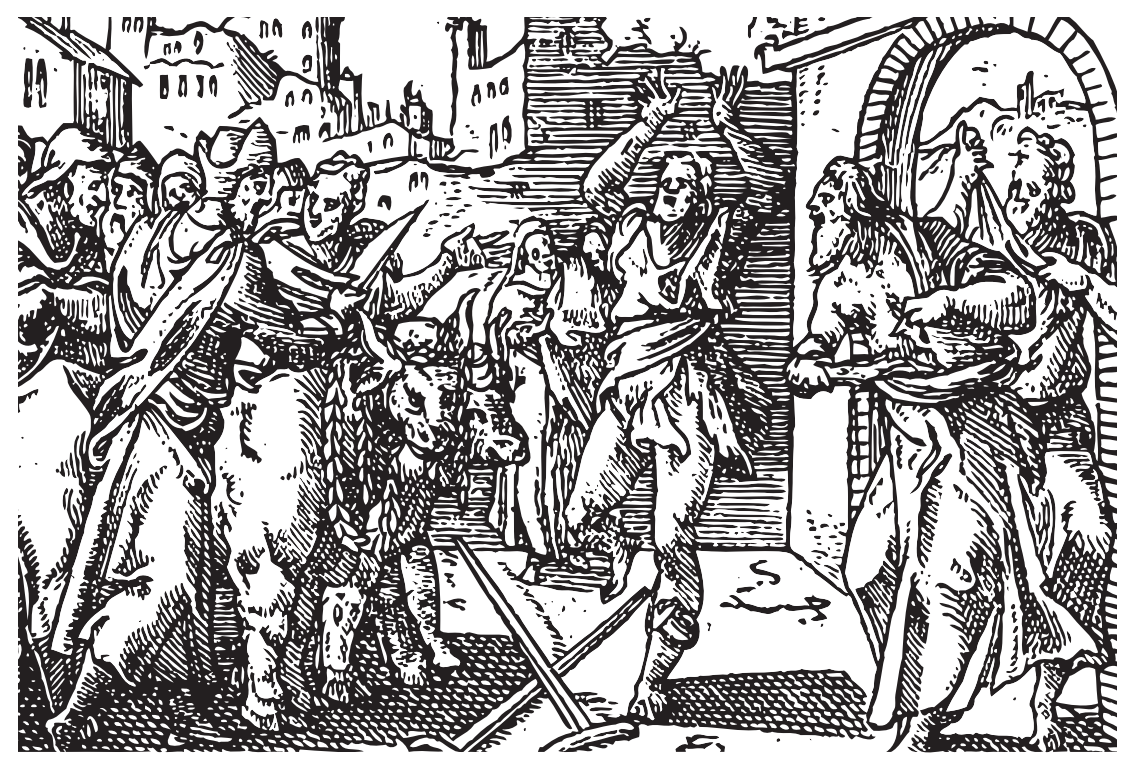

I I. Grabado de la Biblia con toros enguirnaldados. Tomado de la Biblia sacra ad vetustissima exemplaria castigata..., op. cit. (infra n. 2I), cap. XIV, p. 356.

dados. Por ejemplo, en los Hechos de los apóstoles, XVI, I-I4, se explica cómo Pedro curó a un cojo frente al templo de Zeus. Después del milagro, los sacerdotes trajeron "toros enguirnaldados" para ofrecerlos en sacrificio (fig. II). ${ }^{2 \mathrm{I}}$ $\mathrm{El}$ animal del grabado mueve su pata derecha, dando la impresión de estar en movimiento, y su cuerpo está arropado por una tela. El toro representa el sacrificio de José, cuya ardua historia bíblica se reconoce gracias a la decoración.

En la pintura, José se vuelve hacia atrás y observa a Zéfira, quien tira de su capa. El personaje principal del triunfo porta un estandarte con asta en forma de cruz cuyas extremidades superiores rematan en tres esferas. En el lienzo, decorado con dos borlas, una en la parte inferior y otra en la superior, se representa un panal con varias abejas que vuelan a su alrededor. Una cinta une

2I. En una Biblia de 1569 se ilustró el suceso con dos toros que poseen la misma ornamentación. Véase Biblia sacra ad vetustissima exemplaria castigata, necnon figuris \& chorographicis descriptionibus illustrata, apud Guliel Rovillium sub scuto Veneto, Lugduni, Apostolorum, I569, cap. XIV, p. 356. 
el bastón con el banderín que ondea agitadamente e imprime gran movilidad a la imagen.

La tradición emblemática de la segunda mitad siglo XVI y principios del XVII presenta dos aspectos muy relacionados con el grabado, en particular con la colmena. En el libro de Sebastián de Covarrubias de i6ıo, la habitación de las abejas se relaciona con la "dulzura de la gloria". A pesar del camino tortuoso de la vida (y de la muerte), el objetivo es mantener la virtud para lograr la gloria. Covarrubias lo explica en el emblema 7, cent. I, f. 7: Ex amaritudine dulcedo (de lo amargo, lo dulce). El explicatio refiere: "Tomamos de nuestra voluntad, y con buen ánimo la purga que nos da el médico, no embargante más amarga que la mesma hiel, poniendo la mira en que con ella hemos de alcanzar la salud". 22

La otra interpretación proviene de Francisco Núnéz de Cepeda, S.J., quien en la empresa $\mathrm{I}$, La casa guarda el Pudor, menciona que las abejas se hallan estrechamente unidas a la castidad:

Entre sus buenas calidades, descuella como la más admirable la castidad [...] De donde el corcho de las abejas dio a esta empresa cuerpo proporcionado para significar la honestidad, el recato que debe resplandecer en el prelado y en su familia, siendo uno y otro dechado de castidad a los pueblos. ${ }^{23}$

Finalmente, el estandarte con el emblema es rematado por un ave ubicada exactamente sobre la punta superior de la colmena. Santiago Sebastián sugiere que quizá remita al ave fénix, a "su paciencia para conseguir su triunfo de la concordia", y que puede relacionarse con la victoria para lograr la gloria. ${ }^{24}$

En la esquina superior izquierda del grabado encontramos un monte donde se realizan varias acciones. Debido a la disposición del espacio, en el caso del convento novohispano no se representó el cerro y sólo se colocaron las imágenes en el segundo plano de la composición. En el grabado figuran seis hombres que meten a un hombre desnudo en un hoyo. El motivo se complementa con un rebaño de ovejas al lado derecho y varios personajes en la zona posterior. En el convento novohispano, se distingue sólo una figura al fondo,

22. Sebastián de Covarrubias Horozco, Emblemas morales, Madrid, Luis Sánchez, I6Io, f. 7.

23. Francisco Núnez de Cepeda, Idea del buen pastor copiada por los santos doctores representada en empresas sacras, León, Anisson \& Posvel, I6I2, empresa I7.

24. Jesús María González de Zárate (ed.), Real colección de estampas de San Lorenzo de El Escorial, Vitoria, Ephialte/Universidad del País Vasco-Patrimonio cultural, I993, t. III, p. 33. 
aunque, debido a ciertos rasgos y a la similitud de la copia, es probable que se hayan dibujado los tres motivos. Los individuos de este motivo tienen varas en las manos y vestimenta hasta las rodillas. Esta escena secundaria del Triunfo... tiene su fuente iconográfica en la Biblia (Génesis, XXXVII), donde se refiere que José, después de haber tenido varios sueños proféticos, fue a Dotayin a buscar a sus hermanos, quienes lo envidiaban mucho por ser el preferido de su padre. Cuando José se acercaba a sus hermanos, ellos dijeron: "Mirad, ahí viene el de los sueños; vamos a matarle y le arrojaremos a uno de estos pozos, y diremos que le ha devorado una fiera; así veremos de qué le sirven sus sueños" . ${ }^{25}$ Así, los hermanos lo arrojaron en un pozo vacío que no contenía agua. El grabado y la pintura muestran este suceso y llevan a cabo un salto cronológico que conduce hasta el encuentro con Zéfira.

La Biblia explica que José, una vez en Egipto, se convirtió en criado de Putifar, ministro del faraón y jefe de la guardia egipcia, y que, como "era de hermosa presencia y buen rostro", ${ }^{26}$ la esposa del funcionario intentó acostarse con el sirviente. La mujer insistía y José la rechazó en continuas ocasiones, hasta que un día, cuando "entró José en la casa para cumplir con su cargo, y no había nadie [más] en ella, le agarró por el manto, diciendo: 'Acuéstate conmigo'. Pero él, dejando en su mano el manto, huyó y se salió de la casa”. ${ }^{27}$ Este relato es la representación básica del Triunfo...

Observamos que detrás del animal está Zéfira desnuda y que sólo alcanza a cubrirla un paño del que está amarrada con un nudo al toro; su cabello es largo, casi llega al suelo, y está trenzado. Este personaje femenino observa fijamente a José mientras tira de su túnica, al mismo tiempo que le desnuda los hombros y el pecho. Atrás de esta mujer se encuentra otra que participa en la acción. Su aspecto es el de una anciana. Un manto largo, que sostiene con su mano derecha, rodea su cuerpo de la cintura para abajo. Lleva el cabello desaliñado y dirige fijamente la mirada hacia Zéfira. Su papel en la composición es el de espectadora en la "lucha" que llevan a cabo los personajes principales y su movimiento es nulo, aunque su cercanía con Zéfira está muy acentuada y sus músculos y su mirada presentan la gran dureza de la imagen. Esta mujer personifica la envidia y con la mano derecha aprieta con fuerza su corazón, que se lleva a la boca. La tradición emblemática del siglo xvi en el libro de

25. Génesis, XXXVII, I9.

26. Génesis, XXXIX, 6.

27. Ibidem, I I-I 2 . 
Andrea Alciato explica (fig. I2): "Por declarar la Invidia y sus enojos/ pintaron una vieja que comía/víboras, y con mal continuo, de ojos./ Su propio corazón muerde a porfía" ${ }^{28}$ En el Convento de Meztitlán ya no quedan rastros de esta figura y sólo se alcanza a distinguir una parte de su manto, pero es imposible observar la adaptación que realizó el pintor novohispano.

En el segundo plano hay varios elementos que complementan la interpretación iconográfica de la imagen. Arriba de José figura un círculo brillante, con un rostro que observa con fijeza a Zéfira; tal vez se trata del Sol, marco de la gloria del triunfo de José y el acompañante en su camino victorioso.

Respecto a los rasgos de la composición, se copiaron casi íntegramente del grabado y se utilizaron los mismos recursos para dar la impresión de espacio y volumen. Al igual que en el grabado, se usó el blanco, el negro y una gama extensa de grises para definir los músculos del animal, crear la perspectiva y determinar los planos. Las figuras, sus posturas y el movimiento de sus articulaciones se respetaron en su mayoría respecto a los rasgos del grabado. Sólo hay uno con el que tuvieron problemas estilísticos los pintores novohispanos: la única diferencia posible entre la pintura del convento y el grabado es el pie izquierdo de José, que en la pintura mural no mantiene su postura "natural" y, antes bien, da la impresión de estar de frente al espectador, hasta el punto en que se puede observar el alargamiento de los dedos.

Las inscripciones del grabado son amplias; en la pintura mural hay dos palabras en la parte inferior: Castitatis trivmphs. En el grabado de Coornhert (fig. 3) figuran los nombres de los personajes, que en la pintura debieron repetirse, pero se perdieron. En la zona inferior del grabado aparece esta explicatio:

Impia facta fratrum, macra invidia ista figurans,
Vicit IOSEPHUS fidei virtute et amorem
Illicitum ZEPHIRACH candore animi superavit:
Illius omnipotens DEUS alman virginitatem
Servavit sibi in incensum, pinguis bouis instar,
Tristia fata Chanam patriae quo exhauriat olim. ${ }^{29}$

28. Andrea Alciato, Los emblemas de Alciato. Traducidos en rimas españolas, Lion, I549, Rafael Zafra (ed.), Madrid, José J. de Olañeta, 2003, p. 220.

29. "Los actos impíos de los hermanos, figuran como gran envidia,/ José venció con confianza en la virtud y el amor/ los ánimos de la malvada Zéfira superó con candor:/ aquel que al omnipotente Dios [ofreció] su santa virginidad/ encendido dedica, también un fuerte clamor,/ triste destino de la patria de Canán donde solía agotarse" (trad. del autor). 


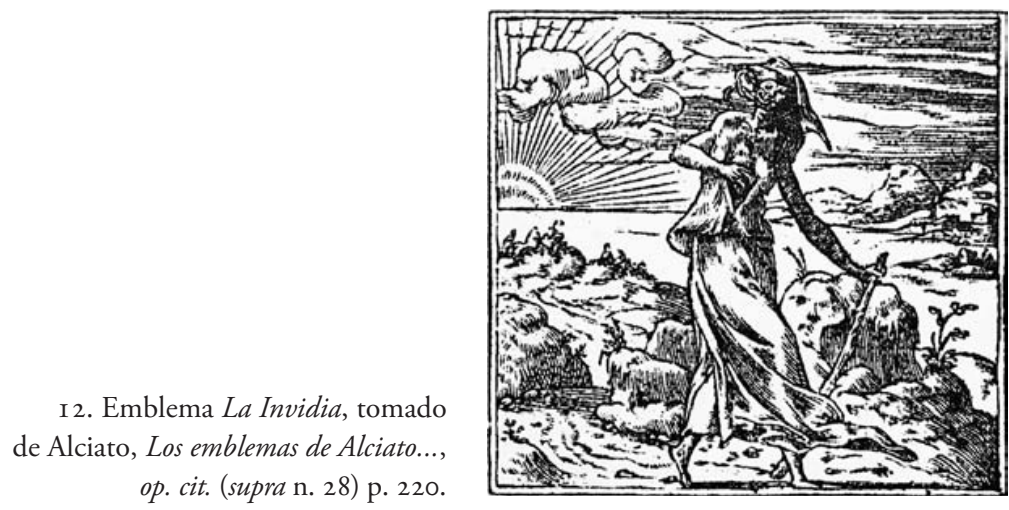

El patriarca José prefigura a Cristo por las acciones de su vida referidas en el Antiguo Testamento. Isidoro de Sevilla hace notar que José "en general fue traicionado, como Jesús, por su familia, y que, como él, fue acogido por una nación extranjera". ${ }^{30}$ Por eso es importante el blasón con el panal de abejas, pues muestra la relación iconográfica entre los dos personajes. Podría advertirse en ese motivo que la vida de José y su triunfo es una figura de la vida de Cristo y su victoria sobre la traición. La historia de José y de la mujer de Putifar remite de modo directo a la Pasión de Cristo. "La mujer de Putifar es la Sinagoga acostumbrada a cometer adulterio con los dioses extranjeros; trata de seducir a Jesús, que rechaza su doctrina y que finalmente deja entre sus manos su manto, es decir su cuerpo, del que se despojó en la cruz." ${ }^{\text {I }}$ De ahí que el Triunfo... exprese su victoria sobre la traición, que lo llevó a la muerte humana, pero de la cual salió vencedor.

Uno de los aspectos más interesantes de la imagen es el vínculo entre la traición y la castidad. La historia de José comprende ambos conceptos. Más allá de un "triunfo moral", representativo de las virtudes del creyente, es también una prefiguración que une la iconografía del claustro bajo con la escalera y el claustro alto. Jesús, al igual que José, fue traicionado; por lo tanto, presenta una prefiguración tipológica: "que mayor es el pecado de quien por envidia entrega a la justicia al inocente, para ser sacrificado, que el de la misma justicia

30. Émile Mâle, El arte religioso del siglo XIII en Francia, Abundio Rodríguez (trad.), Barcelona, Encuentro, 200I, p. I87.

31. Ibidem, p. I88. 
dándole muerte por miedo a un poder superior". ${ }^{32}$ La escalera se presenta en la construcción conventual como el medio simbólico de la unión entre dos "mundos teológicos" o dos áreas arquitectónicas.

Sin embargo, debemos recordar la importancia de las virtudes en el ámbito cenobítico y eremítico. La castidad era fundamental en la vida religiosa y, como la impureza corporal se expresaba perfectamente por medio del contacto físico, tal virtud favorecía una unión más estrecha con el mundo de lo intangible, permitía recuperar la nitidez y claridad de espíritu y lo sagrado, y ponía freno, con base en la tradición judía, a las impurezas. La renuncia del cuerpo era necesaria para alcanzar un estado físico superior, mejorar y facilitar la oración. Como ya indiqué, para los anacoretas y cenobitas de los primeros siglos del cristianismo la abstinencia era una de las formas de la mortificación. ${ }^{33}$ Por ello, con el tiempo se transformó en uno de los fundamentos de las reglas monásticas y de los votos de las comunidades religiosas, tanto femeninas como masculinas.

\section{El Triunfo de la Paciencia}

La segunda imagen de la escalera, ubicada exactamente enfrente del Triunfo de la Castidad, es también parte de la serie de grabados de Maarten van Heemskerck (figs. 4-5). El título del grabado es Patientia.Trivmphus. Las demás inscripciones hacen referencia a los personajes de la acción, los grabadores y al autor de la composición: "Spes/ Desiderum/ Patiential Fortunal/ M. Invet./ DCD Coornhert/ fecitl/:Inven./ H. Cock excud//Patiential Trivmphvs/l. I DVCF".

La imagen comienza con la Paciencia, sentada en un cubo sobre un carro; a su lado, un cordero la observa. La importancia del cubo nos remite a los Emblemata de Alciato en la imagen (fig. I3): "Que el arte ayuda à naturaleza: Fortuna en una bola, y en un quadrado/ Mercurio está, que las artes enseña,/ como los casos revolver es dado/ a la Fortuna, que de esto se enseña”. ${ }^{34}$ En este

32. San Agustín, Tratado sobre el evangelio de San Juan. Obras completas de san Agustín, Madrid, Biblioteca de Autores Cristianos, 1958, trat. CXVI, 5, p. 689.

33. Agnès Gerhards, Dictionnaire historique des ordres religieux, París, Fayard, I998, p. 32.

34. Alciato, op. cit., emblema Que el arte ayuda à naturaleza, p. 234. Sobre el papel del cubo en la tradición pictórica del siglo xvi en Nueva España, veáse Pablo Escalante Gonzalbo, "Humanismo y arte cristiano-indígena. La cultura emblemática entre colegiales, artistas y otros miembros de las elites nahuas del siglo xvI”, en Pablo Escalante (coord.), El arte cristiano-indigena del siglo XVI 
13. Emblema Que el arte ayuda à naturaleza, tomado de Alciato, Los emblemas de Alciato..., op. cit. (supra n. 28), p. 234.

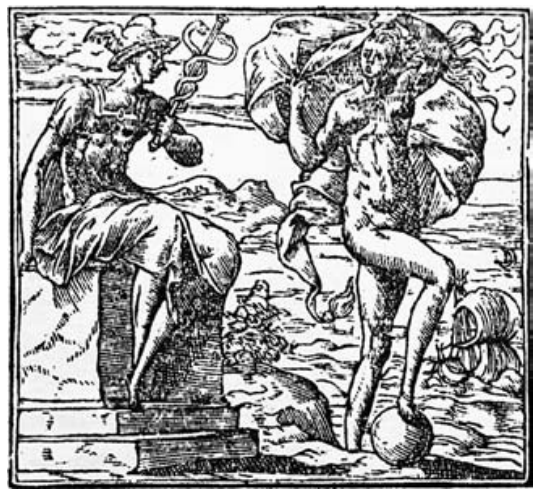

caso, el asiento en forma de cubo se relaciona con la sabiduría y constituye la base virtuosa de la Paciencia en su camino victorioso.

Con su mano derecha, el personaje sostiene un estandarte con una flor rodeada de otros motivos vegetales. Santiago Sebastián explica que "la Paciencia porta como blasón la flor entre espinos, aspecto iconográfico que remite a la virtud, tras el sufrimiento, como apreciamos en los emblemas"; 35 con su mano izquierda, ella sostiene la base de un yunque, sobre la cual hay un corazón en llamas con mucho humo, al que golpean tres martillos.

Atrás, la Fortuna, con una venda en los ojos, tiene el cabello suelto y su vestido está sujetado al carro. Ella intenta cortarlo, pues en la mano derecha tiene una navaja, aunque parece que el movimiento la arrastra y que el "triunfo" será inevitable. La iconografía de la Fortuna también tiene su fuente en los emblemas de ese periodo y, en el caso del grabado, la representación está unida estrechamente al emblema La Ocasión: la coyuntura del tiempo es personificada por una mujer en los emblemas de Andrea Alciato y los atributos de la navaja y la rueda (fig. I4):

Estoy en lo más alto y más subido

De aquesta rueda, porque siempre ruedo.

Y el pie de leves alas es fornido

novohispano y sus modelos europeos, Cuernavaca, Centro de Investigación y Docencia en Humanidades del Estado de Morelos, 2008, pp. 9-27.

35. González de Zárate (ed.), Real colección de estampas..., op. cit., t. III, p. 32. 
Porque parar no pueda no estar quedo.

Y para declarar mi delgadeza

Y quanto desatar y cortar puedo

Navaja traigo de gran agudeza.

Y porque a quien topare pueda asirme

Cabello dio delante a mi cabeza. ${ }^{36}$

El yunque con el corazón y los martillos puede interpretarse de múltiples formas. En el ámbito de los emblemas, este objeto se relaciona con la fortuna. En el libro de Sebastián de Covarrubias de I6Io, encontramos el emblema Suae quisque fortunae faber (cada una forja su propia fortuna). ${ }^{37} \mathrm{El}$ sentido del grabado es la capacidad de controlar a la fortuna, pues cada persona, por méritos propios, decide cómo llevar su camino. En otro emblema se presentan el martillo y el yunque como instrumentos de la fortuna. En el emblema que lleva el mote No por eso se pierde su valor y peso, el epigrama incluye estos versos: "El golpe de la fortuna, aunque quebrante,/ con hazienda, y salud próspero estado,/ no haze mella, en la virtud constante,/ ni en el valor de un sano pecho honrado". ${ }^{8}$ Y la explicatio reza así:

Todas quantas adversidades pueden suceder en un hombre, son de poca consideración, como la conciencia esté sana, aunque la fortuna, con el martillo de los trabajos, atormente, y quebrante, hazienda, salud y vida, pues el valor de la virtud no pierde por esto, antes se mejora, con la tolerancia y la paciencia. ${ }^{39}$

Frente a esto hay una unión precisa en el siglo xvi entre la Paciencia-Yunque-Fortuna, expresada mediante los motes y explicatio de los emblemas. El yunque, por su dureza, resiste los "golpes" de la fortuna; por ello, es el modelo de quien sufre y busca la paciencia con un carácter virtuoso y controlado. El fuego y el corazón tienen, como los otros elementos del grabado, íntima relación con la emblemática de la época. En el emblema de Andrea Alciato Que el virtuoso Amor venze à Cupido, la flama, como recurso pictórico, ocupa un lugar predominante. La explicatio del emblema refiere:

39. Idem (las cursivas son mías). 


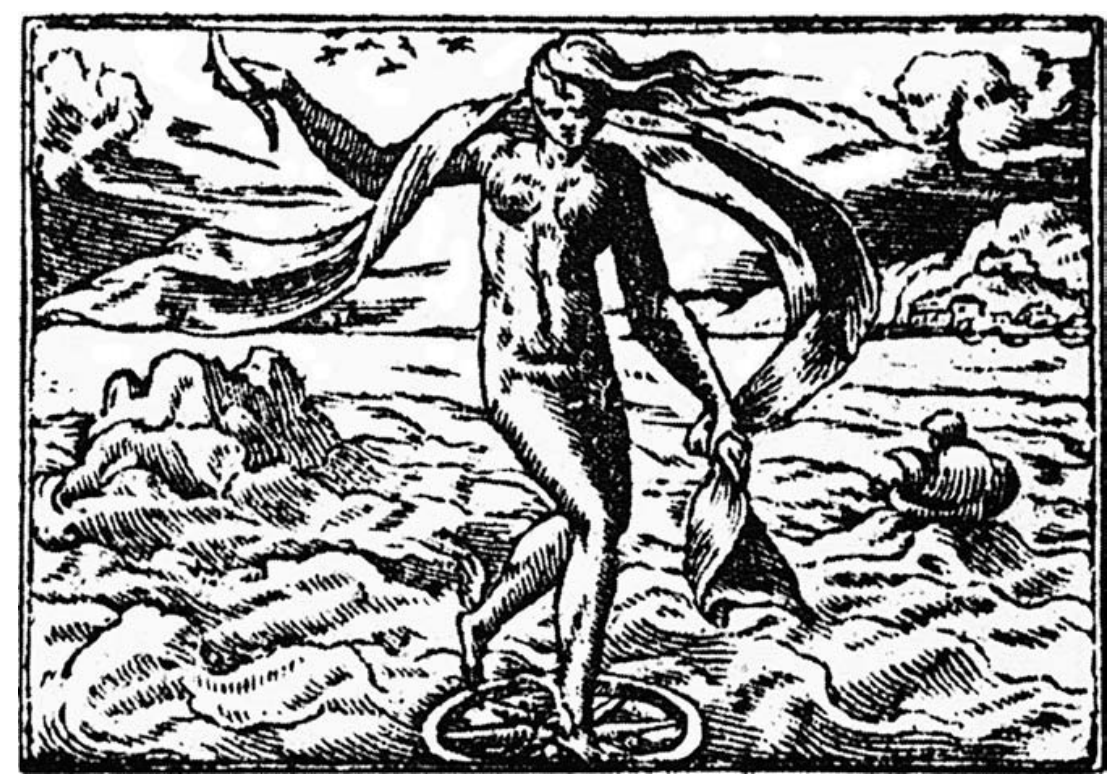

I4. Emblema La Ocasión, tomado de Alciato, Los emblemas de Alciato..., op. cit. (supra n. 28), p. 36.

Al fuego d'el Amor con otro fuego, Con arco a'l arco, a alas con las alas La Némesis domó, porque Amor ciego

(Como las hizo) sustrae cosas malas.

No le basta llorar, no basta ruego,

Escúpase tres veces en sus galas,

Con fuego el fuego (gran cosa) se inflama

D’el Amor aborrece Amor la llama. ${ }^{40}$

El mensaje de la imagen con el fuego del corazón se acerca a la búsqueda del espíritu virtuoso, sobre todo en el contexto del yunque y las herramientas de hierro.

Por lo tanto, Cupido, que personifica al Deseo, y la Esperanza, con su ancla, tiran del carro de la Paciencia. El primero dirige la comitiva con las cuerdas amarradas a su cintura; tiene sus alas, su carcaj y su arco en la mano derecha. Levanta 
su brazo izquierdo y a su alrededor se aprecia una serie de círculos que provocan efecto de luminosidad. Estos trazos figuran a la misma altura que el Sol del Triunfo de la Castidady pueden relacionarse con la majestuosidad de la victoria.

El grabador representó un barco a punto del naufragio y un bote en el fondo de la imagen. La navegación se vincula de manera directa con los emblemas del siglo xvi: primero con la Fortuna, pues en los emblemas de Alciato ya citados, relacionados con ella (La Ocasión y Que el arte ayuda à naturaleza), siempre está presente el barco; y, si en la estampa se establece una unión con la esperanza, lo mismo ocurre en el emblema de Alciato:

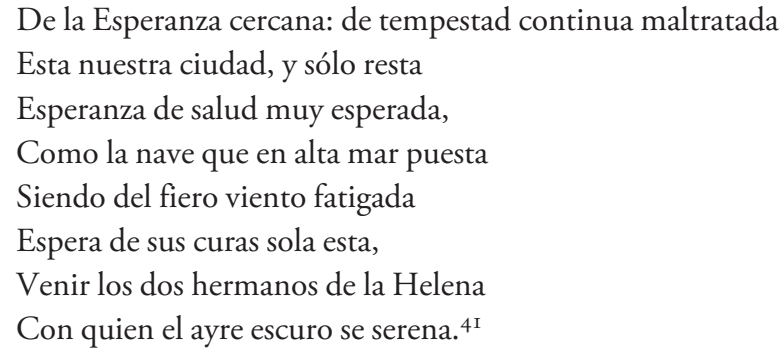

Por lo tanto, el barco representa la unión entre las dos partes del grabado y remata el mensaje compositivo, es decir, el final del carro (con la Fortuna) y el principio (con la Esperanza y su ancla a cuestas).

Uno de los aspectos más relevantes del grabado es la explicatio, pues además de la iconografía aporta nuevos elementos de análisis:

Ac velut angustas rosa candida pullulat inter
Spinas, nec premitur: florent et lilia Vere:
Sic iam magnifica vehitur PATIENTIA Curru,
CUI FORTUNA potens, fractis concessit honorem
Viribus, et vinclis sequitur constricta, pudore:
Hunc SPES alma trahit, volucri STUDIO comitata. ${ }^{42}$

4I. Ibidem, emblema La Esperanza cercana, p. 56.

42. "Así como la débil rosa cándida brota entre/ las espinas, sin prisas: y los lirios florecientes en la primavera:/ así la magnífica Paciencia es transportada en el carro/ cuya potente Fortuna, concede honor accidentado/ a los hombres, y el Pudor transcurre con apretada atadura:/ éste conduce el alma a la Esperanza, y lo acompańa con ligero afán” (trad. del autor). 
Esta frase incorpora un nuevo rasgo al estudio de la relación entre el pudor, la espera de la gloria — como las flores esperan la primavera - y la paciencia, pues por medio de estos versos observamos la consolidación de la imagen.

Estas pinturas son emblemas codificados, cuyo lenguaje sólo era reconocible para un público con conocimientos de la teología y la tradición emblemática. Es indudable que los frailes del Convento de Meztitlán prefirieron tal tipo de mensajes, aunque resta investigar si este último constituye una innovación común a toda la orden en Nueva España o sólo un discurso regional relativo a una casa de estudios particular de frailes agustinos en el siglo XvI.

\section{Las virtudes agustinas y la emblemática cristiana en la escalera}

Según san Agustín de Hipona, la Paciencia es la virtud "por la que toleramos con igualdad de ánimo los males para no abandonar con iniquidad de ánimo los bienes, bienes por los que hemos de alcanzar otros superiores". ${ }^{33}$ Por tanto, la esperanza desempeña un papel predominante en el Triunfo de la Paciencia. Según la teología agustina, la función de la paciencia es aceptar los males de esta vida, pues en un futuro se recompensarán con una "gloria eterna" 44 donde el anhelo ayudará a soportar los embates del mundo terrenal. La imagen representa pues la paciencia del espíritu, es decir, la que se expresa por medio de obras que no podemos dominar. Por tanto, señala san Agustín, el único medio para obtener la paciencia virtuosa es acercarse a Dios, quien infunde la esperanza que fortalece el espíritu: "A Dios vive sumisa mi alma, porque de Él procede mi paciencia". 45

Los personajes que rodean a la figura central son personificaciones de un mundo incontrolable para los humanos: como la Fortuna o el Deseo. De ahí que la fuerza de ese "espíritu cristiano" sea el único método para lograr sobrepasar esas potencias y "triunfar". San Agustín sentencia: "Mayor es el combate de la paciencia cuando no se trata de un enemigo visible, que con la persecución y furor incite al mal". ${ }^{46} \mathrm{El}$ ejemplo más evidente de estas ideas en la composición de la pintura es el deseo personificado por Cupido. Tal

43. San Agustín, Obras de san Agustín. Tratados morales. Sobre la paciencia, Lope Cilleruelo (trad.), Madrid, Biblioteca de Autores Cristianos, 1954, cap. II, 2, p. 437.

44. Ibidem, cap. III, 3, p. 439.

45. Salmos, LXI, 6, apud. San Agustín, Sobre la paciencia..., cap. XV, I2, p. 453.

46. Ibidem, cap. X, 9, p. 447. 
personaje es problemático por sus capacidades, ya que puede tentar, pero el pudor siempre encuentra un camino para vencerlo. Las acciones humanas se vuelven dañinas porque existe la tentación de pecar; por esa razón, la paciencia cristiana se enfrenta a Cupido-deseo para dar un mensaje de cautela al creyente.

San Agustín recuerda que en la Biblia hay una referencia directa a la paciencia en el libro de Job:

Hijo, al acercarte al servicio de Dios, mantente en justicia y temor y prepara tu alma para la tentación. Humilla tu corazón y aguanta, para que al fin crezca tu vida. Acepta todo lo que te sobrevenga, aguanta en el dolor y ten paciencia en la humildad. Porque a fuego se prueban el oro y la plata, pero los hombres se hacen aceptables en el camino a la humillación. ${ }^{47}$

Además del carácter emblemático del yunque, esa descripción del padre de la Iglesia explica por qué la personificación de la paciencia sostiene un corazón del que brota humo, pues en ese órgano se toman las decisiones basadas naturalmente en el libre albedrío y es el lugar de la voluntad humana, aunque - como la imagen lo expresa - con la limitante del elemento del humanismo renacentista de la fortuna..$^{4}$ En los textos clásicos griegos y romanos la Fortuna es una diosa, es una mujer — como en el caso de la imagen novoshipana-, y, para los tratadistas políticos del Renacimiento, este personaje se siente atraído por el vir: el hombre de verdadera hombría. Una cualidad que le gusta recompensar de manera especial es el valor viril. Pero el talante que ella más elogia entre todos es la virtus, atributo epónimo del hombre verdaderamente viril. En el ámbito del cristianismo renacentista, la Fortuna es ciega, no se deja influir y, como vimos, su símbolo ya no es la cornucopia, sino la rueda que gira forzosamente como la pleamar y la bajamar de la marea — también por eso el barco figura en el fondo del grabado. La Fortuna es una ancilla Dei para la magnanimidad en la providencia de Dios. Por lo tanto, durante el siglo XvI la concepción de la Fortuna como ancilla Dei se modificó porque retornó la antigua idea de la distinción entre Fortuna y Hado (divinidad o fuerza desconocida que obraba irresistiblemente sobre las demás divinidades, los hombres

47. Ibidem, cap. XIV, II, p. 45 I.

48. Quentin Skinner, Los fundamentos del pensamiento politico moderno. I. El Renacimiento, Juan José Utrilla (trad.), México, Fondo de Cultura Económica, I999, pp. 38-4I. 
y los sucesos). En ese sentido, según el humanismo cristiano, el hombre debe encontrar la libertad de la voluntad por medio de la virtud de Dios, y por eso los humanistas atacaron de modo constante a los astrólogos. Por ejemplo, Nicolás Maquiavelo, en su tratado El príncipe, señala a la fortuna como "la ocasión propicia": "sin esa ocasión sus méritos de nada hubieran valido [aunque exista una voluntad constante]; pero también es cierto que, sin sus méritos, era inútil que la ocasión se presentara". Los favores de la Fortuna están en los hombres con valor, audaces, "menos cautos, más impetuosos [...], más sensibles a la virtus del verdadero vir". ${ }^{49}$ Evidentemente, el carácter civil de los tratados políticos marca una división importante con la "fortuna cristiana" del convento agustino novohispano; el objetivo del político, según Maquiavelo y otros tratadistas, es seducir a la mujer fortuna para obtener honor y fama. No hay duda de que los frailes del convento tenían otra perspectiva, pues el propósito del Triunfo... era lograr el acercamiento con Dios y la imitación del personaje bíblico. A pesar de tales divergencias conceptuales, estos aspectos representan una preocupación de la época que se mantuvo en la emblemática hasta principios del siglo XvII.

La imagen del convento novohispano representa un equilibrio muy propio del cristianismo renacentista, cuyos fundamentos se plasman en el llamado humanismo cristiano de principios del siglo xvi. Por un lado, la voluntad convive con la fortuna y, por otro, la importancia fundamental de la esperanza en la vida eterna es la transformación de una paciencia basada en lo "terreno", en una Paciencia "celeste", "sagrada": "para la paciencia verdadera no se basta la voluntad humana si no es ayudada e inflamada desde arriba, porque el Espíritu Santo es su fuego".$^{50}$ La oveja es el complemento iconográfico de este planteamiento. En la Biblia, tanto en el Antiguo como en el Nuevo Testamento, se hacen constantes referencias a este animal y se le relaciona con el alma del creyente: “¿Quién nos separará del amor de Cristo? ¿La tribulación, la angustia, la persecución, el hambre, la desnudez, el peligro, la espada? Según está escrito: 'Por tu causa somos entregados a la muerte todo el día, somos mirados como ovejas de degüello'". ${ }^{5 I}$ Las últimas palabras provienen del salmo XLIV, 23, donde se relaciona al justo con la oveja y, sobre todo, se argumenta que los

49. Nicolás Maquiavelo, El príncipe, Helena Puigdomènech (trad.), México, Rei, I994, p. I4 (las cursivas son mías).

50. Ibidem, cap. XVII, I4, p. 457.

5I. Romanos, VIII, 35-36. 
males que padece los causa Dios. Por tanto, el hombre, como oveja, debe aceptar el sacrificio para poder alcanzar otro plano de salvación. Así se establece en la Biblia: "porque os ha sido otorgado no sólo creer en Cristo, sino también padecer por Él". ${ }^{52}$ Uno de los objetivos de la comunidad de creyentes es sufrir por la fe en Jesús.

Una de las virtudes que más resalta Gregorio Magno es la paciencia cuando explica que Jesús en su sufrimiento se mantuvo en la cruz pese a que la población lo conminaba a liberarse si era realmente el rey de los judíos (Mateo, XXVII, 42). Cristo manifestó la virtud de la paciencia, ya que "no quiso bajar de la cruz, se levantó del sepulcro; que levantarse del sepulcro fue más que bajar de la cruz; más fue destruir la muerte resucitando que conservar la vida descendiendo". ${ }^{53}$ Así, los hombres deben "purificar" su corazón con la sabiduría de Dios para contemplar la luz. "El polvo, la pituita y el humo son los pecados y las inquietudes. Quita de tu corazón todo esto y gozarás entonces de la presencia de la Sabiduría, que es Dios." 44 La "purificación" se alcanza por medio de Dios y el seguimiento de la castidad y la paciencia.

\section{Conclusiones}

Los pintores conjuntaron los siguientes elementos en el refectorio: el sacrificio de la sangre de Cristo, los agustinos penitentes con sus flagelos y la región de Meztitlán. Un primer análisis revela que la pintura del refectorio basa sus planos y su perspectiva en la percepción del espacio de los mapas de la segunda mitad del siglo Xvı, con límites manifiestos desde un solo punto de vista que se inserta en el medio círculo de la estructura arquitectónica. Con base en el uso de los planos, observamos que las escalas de los personajes y del medio sugieren la importancia de las figuras. Hay una relación, pues, entre la "escala espacial", entre horizontales o verticales, sobre la superficie y los planos, por un lado, y, por otro, la jerarquía que se representa. Evidentemente, los religiosos exteriorizan una primacía compositiva fundamental: después de Cristo, el nopal cruciforme, las construcciones y el medio -incluido el terreno montañoso y la vegetación.

52. Filipenses, I, 29.

53. San Gregorio Magno, Cuarenta homilias sobre los Evangelios, en Obras completas de Gregorio Magno, Madrid, Biblioteca de Autores Cristianos, I958, lib. II, h. I [2 I], 7, p. 636.

54. San Agustín, Tratado sobre el evangelio..., op. cit., trat. XXII, I2, t. I, p. 585. 
Los agustinos, indiscutiblemente, perseguían una preeminencia sobre el entorno y con tal fin observaban la vegetación, las montańas, las dos iglesias y los edificios civiles — que conferían primacía al territorio como "villa". Cada detalle de la imagen forma parte de un espacio que se define a partir de la creación de los frailes y el papel del sacrificio de Jesús crucificado en esa zona. Del mismo modo, la representación rompe el esquema de la temporalidad, para conformar una "memoria visual" y plantar raíces, sobre todo si las fundaciones indígenas anteriores a los espańoles con mayor jerarquía política eran los pueblos cercanos de Tepatetipa y Malila. ${ }^{55}$

El uso del paisaje con esta representación es de apropiación, es decir, los frailes agustinos justifican y certifican su estancia en esa región así como sus acciones "en favor" de Cristo, quien es su guía y modelo a seguir; incluso el uso del pictograma indígena muestra cómo el religioso y el pintor se apropian de la antigua tradición para relacionarla con la nueva cosmovisión. En la imagen se establecieron dos puntos: la pintura como prolongación del espacio y la representación como secuela de una mirada colectiva de tradición indígena y europea. Por un lado, el creador o creadores del programa iconográfico establecieron en la imagen una jerarquización y, por otro, construyeron una identidad, un papel en ese medio donde los agustinos dominan junto con Cristo crucificado. En general, formularon un discurso visual para mostrar las razones de su estancia en la zona y su primacía sobre el medio y el ámbito civil, representados en la construcción para afianzar una identidad colectiva. En la imagen del refectorio se conjugan la "historia" de la orden en Nueva España, su tradición de ermitańos y el paisaje regional de la villa de Meztitlán con sus "ermitas". El espectador del siglo Xvi (indígena o europeo) observa una guía espiritual que domestica la devoción y, por ende, brinda un control sobre el entorno y la mirada.

Finalmente, el emblema es un medio de "memoria artificial" que contiene de forma resumida los puntos básicos de una reflexión o un discurso. Una de las funciones más importantes del emblema era "implantar" en la memoria de un público amplio enseñanzas morales de carácter universal. El objetivo

55. Véase Federico Fernández Christlieb et al., "El altepetl de Metztitlán y su señorío colonial temprano”, en Federico Fernández Christlieb y Ángel Julián García Zambrano (coords.), Territorialidad y paisaje en el altepetl del siglo XVI, México, Fondo de Cultura Económica/Universidad Nacional Autónoma de México-Instituto de Geografía, 2006. Estos autores consideran que la primera fundación de la zona es la iglesia de Tepatetipa, pero todavía se requiere un análisis arquitectónico más detallado para delimitar las fechas de todos los edificios de la región. 
era que "pudieran ser grabadas en la mente, sin ayuda de grandes libros, todas las reglas de la vida moral y civil". ${ }^{56}$ Los dos grabados copiados en el convento expresan dos virtudes fundamentales de los frailes y religiosos del siglo Xvi. Su lenguaje pictórico reúne rasgos de la emblemática y de la teología. Por tanto, sus composiciones son emblemas en sí mismos por la distribución de sus aspectos, las figuras, las inscripciones y, en particular, el uso pictórico del carro.

Este modelo de imagen se repitió profusamente durante ese siglo y en sus ejemplos se aprecia la unión de varios elementos para crear un discurso teológico de gran complejidad. En el caso de estos grabados y de las pinturas en la escalera, el emblema sobrepasó su simple función de "recordatorio", pues creó conceptos mediante imágenes.

Para entender los grabados emblemáticos del siglo xvi era necesario, en primer lugar, poner en evidencia el proceso de interpretación del texto, de la retórica que alumbra la organización discursiva y "que determina y crea las condiciones mismas en que se da a ver la imagen simbólica". 57 Por tanto, las inscripciones eran fundamentales, ya que complementaban el mundo visual: Heemskerck elaboró los versos y los frailes los conocieron por medio de las estampas. Estas tres pinturas del Convento de Meztitlán intentaron configurar la memoria intelectual, pues el principio del conocimiento se da a través de la analogía y se conoce la realidad por medio de las metáforas continuas. Se utilizó el paisaje como una metáfora pictórica para representar el papel de los frailes en la región. De igual forma, este cúmulo de emblemas y significados - transformado en grabados y después en pinturas de la escalera de un convento novohispano - era un mensaje abreviado donde se formalizaba la vida de los eremitas. Las pinturas murales eran un recurso didáctico para armonizar una realidad religiosa donde la importancia radicaba en crear una organización simbólica del mundo y de la vida conventual. \$

56. Fernando R. de la Flor, Emblemas. Lecturas de la imagen simbólica, Madrid, Alianza, I995, p. 55. 